\title{
Complex hydrides as room-temperature solid electrolytes for rechargeable batteries
}

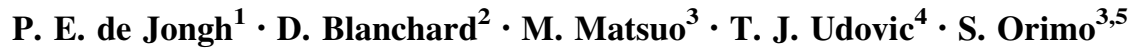

Received: 26 August 2015 / Accepted: 26 October 2015/Published online: 3 March 2016

(c) The Author(s) 2016. This article is published with open access at Springerlink.com

\begin{abstract}
A central goal in current battery research is to increase the safety and energy density of Li-ion batteries. Electrolytes nowadays typically consist of lithium salts dissolved in organic solvents. Solid electrolytes could facilitate safer batteries with higher capacities, as they are compatible with Li-metal anodes, prevent $\mathrm{Li}$ dendrite formation, and eliminate risks associated with flammable organic solvents. Less than 10 years ago, $\mathrm{LiBH}_{4}$ was proposed as a solid-state electrolyte. It showed a high ionic conductivity, but only at elevated temperatures. Since then a range of other complex metal hydrides has been reported to show similar characteristics. Strategies have been developed to extend the high ionic conductivity of $\mathrm{LiBH}_{4}$ down to room temperature by partial anion substitution or nanoconfinement. The present paper reviews the recent developments in complex metal hydrides as solid electrolytes, discussing in detail $\mathrm{LiBH}_{4}$, strategies towards for fast room-temperature ionic conductors, alternative
\end{abstract}

P. E. de Jongh

P.E.deJongh@uu.nl

1 Inorganic Chemistry and Catalysis, Debye Institute for Nanomaterials Science, Utrecht University, Utrecht, The Netherlands

2 Department of Energy Conversion and Storage, Technical University of Denmark, Roskilde, Denmark

3 Institute for Materials Research, Tohoku University, Sendai 980-8577, Japan

4 NIST Center for Neutron Research, National Institute of Standards and Technology, Gaithersburg, MD 20899-6102, USA

5 WPI-Advanced Institute for Materials Research, Tohoku University, Sendai 980-8577, Japan compounds, and first explorations of implementation of these electrolytes in all-solid-state batteries.

\section{Introduction: the relevance of solid-state electrolytes}

The electrolyte in present-day lithium-ion batteries, typically based on oxidic intercalation materials such as lithium cobalt oxide $\left(\mathrm{LiCoO}_{2}\right)$ cathodes and graphite intercalation anodes $\left(\mathrm{Li}_{x} \mathrm{C}\right)$, usually consists of lithium salts dissolved in organic liquids. This enables fast $\mathrm{Li}^{+}$transport between the electrodes, but is associated inevitably with potential safety, stability, and cycle-life issues. Increasing the energy density is a major incentive for battery development and research. A factor of 2-3 in energy density should be gained to render the current driving range (of about $160 \mathrm{~km}$ ) of all electric vehicles competitive to that of petrol-driven cars. Energy density becomes even more critical when considering also medium-scale applications, such as local load levelling of solar energy and wind power [1-4].

Using lighter electrode materials is crucial to attain higher energy densities (see Fig. 1). $\mathrm{Li}_{x} \mathrm{~S}$ is proposed as a next-generation cathode material, with as a major challenge the large volume change upon cycling and the solubility of polysulphides in organic solvents $[5,6]$. The ultimate dream is a cathode reaction of $\mathrm{Li}$ with $\mathrm{O}_{2} / \mathrm{H}_{2} \mathrm{O}$ (lithium-air batteries), with energy densities close to that of gasoline theoretically possible, but for which achieving full reversibility is a major issue to solve [7]. On the anode site, using conversion metal hydrides could lead to higher gravimetric densities [8-14]. Also, metallic lithium anodes have theoretical energy densities even ten times higher than current carbon-intercalation anodes. However, metallic 


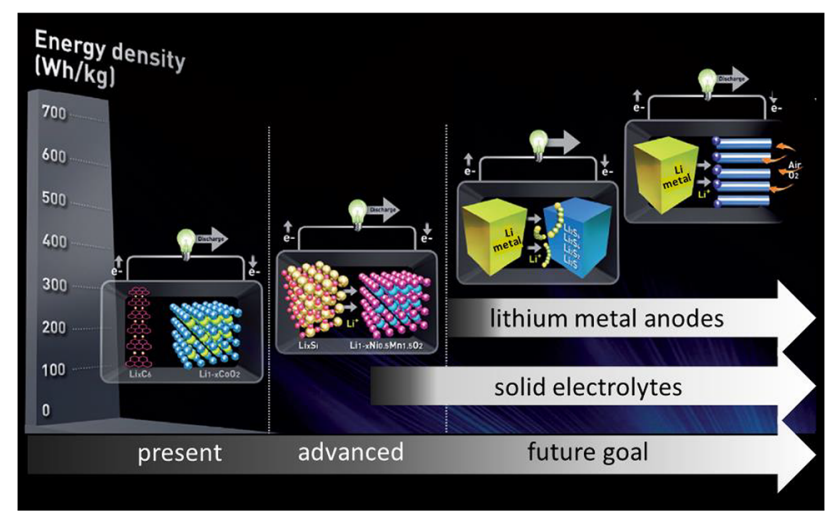

Fig. 1 Illustration of developments towards higher energy density lithium-ion batteries. Modified based on a figure in [2]

lithium is not thermodynamically stable in contact with any organic solvent, and commercialisation of batteries based on Li-metal anodes in combination with liquid electrolytes seems unlikely $[2,15,16]$.

Solid electrolytes could offer compatibility with $\mathrm{Li}$ metal anodes, prevent short-circuiting in sulphur-based batteries, and eliminate the safety risks associated with the flammability and volatility of organic solvents. However, it is a formidable challenge to identify a light-weight and low-cost solid material with sufficiently high ionic conductivity (at least $10^{-4}-10^{-3} \mathrm{~S} \mathrm{~cm}^{-1}$ at room temperature) which at the same time possesses a large electrochemical stability window and has negligible electronic conductivity. For thin film batteries in microdevices, so-called LISICON materials have been developed, of which $\mathrm{Li}_{10-}$ $\mathrm{GeP}_{2} \mathrm{~S}_{12}$ [17] seems one of the most promising ones, but large-scale application is hindered by the high cost of electrolyte fabrication and components. Several other multi-metal oxynitrides and titanates are being considered, but at present no material satisfying all requirements has been identified, and hence the search for new types of solid electrolytes is a very active field of research.

\section{Complex metal hydrides as solid-state electrolytes}

Complex metal hydrides are solids with an ionic lattice composed of metal cations and complex hydride anions in which the atoms are predominantly covalently bound. This family includes boron hydrides such as $\mathrm{LiBH}_{4}, \mathrm{Li}_{2} \mathrm{~B}_{12} \mathrm{H}_{12}$, $\mathrm{NaBH}_{4}$, and $\mathrm{Mg}\left(\mathrm{BH}_{4}\right)_{2}$, aluminium hydrides such as $\mathrm{LiAlH}_{4}$ and $\mathrm{Na}_{3} \mathrm{AlH}_{6}$, and a wide range of other compounds. Several hydrides, such as $\mathrm{LiAlH}_{4}$ and $\mathrm{NaBH}_{4}$, are in wide use as reductants in organic synthesis. Due to their high hydrogen content, they are also considered promising reversible hydrogen storage materials [18-20]. Despite early reports [21], investigation of their potential as solidstate electrolytes has only taken full flight with the pioneering work of the group of Orimo [22, 23].

Like many other boron hydrides, $\mathrm{LiBH}_{4}$, consisting of $\mathrm{Li}^{+}$cations and $\left[\mathrm{BH}_{4}\right]^{-}$anions, can be found in different polymorphs, depending on pressure and temperature (see Fig. 2) [24-27]. The orthorhombic phase, which is the stable phase at room temperature, has a low ionic conductivity $\left(\sim 10^{-8} \mathrm{~S} \mathrm{~cm}^{-1}\right.$ at $\left.30^{\circ} \mathrm{C}\right)$. However, in 2007 it was reported by the group of Orimo that the hexagonal phase, which is stable at temperatures above $110^{\circ} \mathrm{C}$ under atmospheric pressure, has a remarkable high ionic conductivity $\left(\sim 10^{-3} \mathrm{~S} \mathrm{~cm}^{-1}\right.$ at $\left.120^{\circ} \mathrm{C}\right)$ [23]. For actual application in batteries, high ionic conductivities at room temperature are required. Henceforth, the interesting question is whether the high ionic mobilities in $\mathrm{LiBH}_{4}$ can be extended to room temperature or whether alternative complex hydrides having this property are available.

In this section, we start by briefly reviewing the findings on $\mathrm{LiBH}_{4}$ as a fast-ionic conductor, and how the high conductivity behaviour was extended to room temperature by either partial anion replacement (Sect. 3) or the formation of a nanocomposite (Sect. 4). Subsequently, we will also discuss alternative complex metal hydrides with high ionic mobilities, and we will end with a brief conclusion and outlook. More details on complex metal hydrides as solid-state electrolytes can also be found in [28].

\section{Fast room-temperature ionic conduction in $\mathrm{LiBH}_{4}$ by partial anion substitution}

Most notably Orimo and co-workers showed that replacing a fraction of the $\mathrm{BH}_{4}{ }^{-}$anions by halide anions $\left(\mathrm{I}^{-}, \mathrm{Br}^{-}\right.$or $\mathrm{Cl}^{-}$) stabilises the hexagonal structure at lower temperatures and leads to high ionic mobilities persisting down to room temperature. They found the partial replacement of the $\left[\mathrm{BH}_{4}\right]^{-}$anion with $\mathrm{I}^{-}$anions, especially effective. A single-phase solid solution was formed for a wide range of compositions up to $25-30 \%$ of anion replacement. An ionic conductivity of $2 \times 10^{-4} \mathrm{~S} \mathrm{~cm}^{-1}$ at room temperature was obtained, and a minimum activation energy of $0.39 \mathrm{eV}$ at a replacement of $13 \%$ of the $\left[\mathrm{BH}_{4}\right]^{-}$ions. Anion substitution stabilised the high-temperature phase to room temperature, but, as the solid solutions were obtained by ball milling, grain boundaries and defects also seem to play an important role [22, 29].

In the high-temperature phase, the $\mathrm{Li}^{+}$ions are arranged in layers in the hexagonal plane, with probably two nearly equivalent $\mathrm{Li}^{+}$sites. As in principle all sites are filled, the conduction is most likely related to Frenkel-pair defects $\left(\mathrm{Li}^{+}\right.$vacancies combined with interstitial $\mathrm{Li}^{+}$sites). 
Fig. 2 Crystal structures of the (right) low-temperature phase and (middle) high-temperature phase of $\mathrm{LiBH}_{4}$. (left) Isosurfaces of $\mathrm{Li}, \mathrm{B}$, and $\mathrm{H}$ populations obtained by firstprinciples molecular dynamics simulations [24]
High-temp. phase (hexa.)

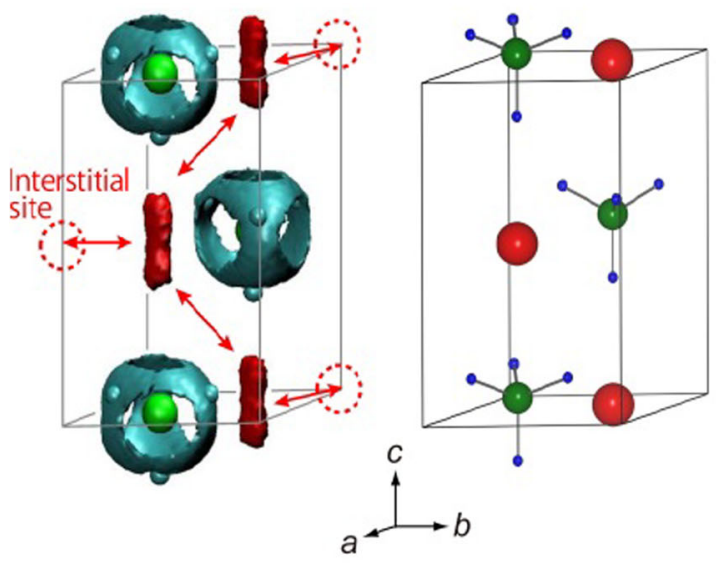

Low-temp. phase (ortho.)
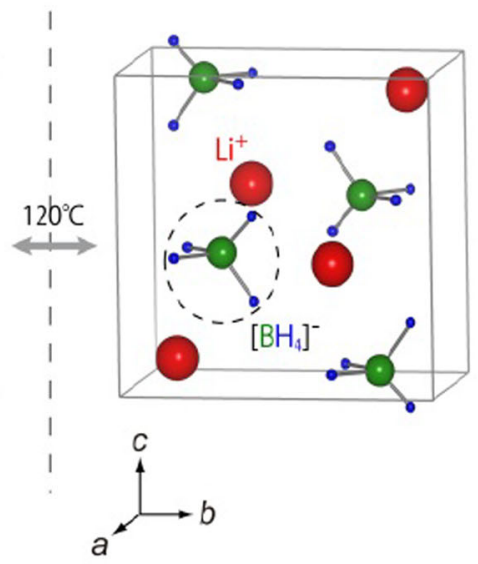

Interstitial $\mathrm{Li}^{+}$can, with a relatively low activation barrier and probably helped by rotation of the neighbouring $\mathrm{BH}_{4}{ }^{-}$ units, jump from one interstitial site to the next (see Fig. 2) $[22,24,29,30]$. In the $\mathrm{LiBH}_{4}$ :LiI solid solutions, the mobilities of $\mathrm{Li}^{+}$and $\left[\mathrm{BH}_{4}\right]^{-}$increase with increasing iodine content [30,31]. Using mixed components was reported to make the system susceptible to phase segregation and reduced thermal and electrochemical stability $[32,33]$.

\section{Fast room-temperature ionic conduction in $\mathrm{LiBH}_{4} / \mathrm{SiO}_{2}$ nanocomposites}

Nanocomposites of light metal hydrides with high surface area carbon materials have been widely investigated for reversible hydrogen storage applications, as creating a large interfacial area between the hydrides and carbon scaffolds has been found to improve the kinetics and reversibility of hydrogen sorption and result in high hydrogen and $\left[\mathrm{BH}_{4}\right]^{-}$mobilities [34-36]. NMR suggested also high $\mathrm{Li}^{+}$mobilities in $\mathrm{LiBH}_{4} / \mathrm{C}$ nanocomposites [35, 37], but carbon materials are electronically conductive, hampering detailed structural studies and ionic mobility measurements and their use as solid electrolytes.

Very recently, it was reported that nanocomposites of $\mathrm{LiBH}_{4}$ with $\mathrm{SiO}_{2}$, prepared by melt infiltration under hydrogen pressure of ordered mesoporous $\mathrm{SiO}_{2}$ scaffolds with $\mathrm{LiBH}_{4}$ [38], displayed very high $\mathrm{Li}^{+}$conductivities $\left(10^{-4} \mathrm{~S} \mathrm{~cm}^{-1}\right)$ at room temperature (Fig. 3) [39]. These are surprisingly high values, given that these nanocomposites comprise a large fraction (up to $50 \mathrm{vol} \%$ ) of insulating $\mathrm{SiO}_{2}$ and also a significant void fraction. The high room-temperature ionic conductivity in $\mathrm{LiBH}_{4}$ by confinement in a mesoporous $\mathrm{SiO}_{2}$ matrix is stable (when

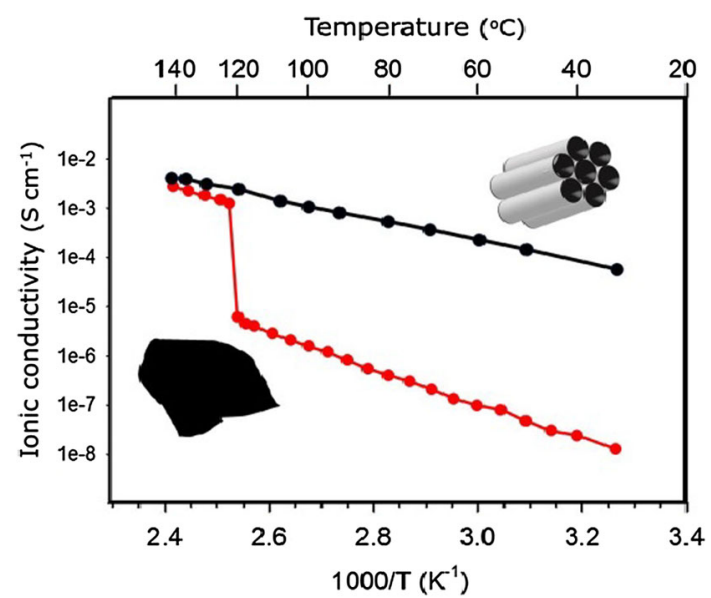

Fig. 3 Ionic conductivities of bulk and nanoconfined $\mathrm{LiBH}_{4}$. Macrocrystalline $\mathrm{LiBH}_{4}$ displays high ion conductivities only in the hightemperature $\left(>110{ }^{\circ} \mathrm{C}\right)$ polymorph. In contrast, the $\mathrm{LiBH}_{4} / \mathrm{SiO}_{2}$ nanocomposite shows high ionic conductivities even at room temperature [39]

temperature cycling to $140{ }^{\circ} \mathrm{C}$, electrochemically cycling $\pm 6 \mathrm{~V}$ ) and reproducible [39].

The origin of the high ionic mobility in these nanocomposites is not yet well understood. Confinement of $\mathrm{LiBH}_{4}$ in the oxide pores leads to limited stabilisation of the hexagonal high-temperature phase in the core of the pores. However, the high ionic mobility seems rather associated with the fraction of $\mathrm{LiBH}_{4}$ that is close to the $\mathrm{SiO}_{2}$ interface $[39,40]$. In general high defect densities and low diffusion barriers are found at the interface between two solids, due to effects such as disorder, strain, and space charge regions. Also for other compounds, mostly studied as proton and oxygen conductors for fuel cells, the addition of oxide nanoparticles has been found to increase conductivity [41-43]. 


\section{Other $\mathrm{Li}^{+}$-containing complex hydrides}

Apart from $\mathrm{LiBH}_{4}$, several other complex metal hydrides have been discovered to display fast conductivity. An interesting family is the system $\mathrm{LiBH}_{4}-\mathrm{LiNH}_{2}-\mathrm{LiI}$. For instance, $\mathrm{Li}_{2}(-$ $\left.\mathrm{BH}_{4}\right)\left(\mathrm{NH}_{2}\right)$ and $\mathrm{Li}_{4}\left(\mathrm{BH}_{-4}\right)\left(\mathrm{NH}_{2}\right)_{3}$ show conductivities of $2 \times 10^{-4} \mathrm{~S} \mathrm{~cm}^{-1}$ at $300 \mathrm{~K}$. Also, lithium aluminium hydrides such as $\mathrm{LiAlH}_{4}$ and $\mathrm{Li}_{3} \mathrm{AlH}_{6}$ are potentially interesting. Reported conductivities until now are relatively low $\left(10^{-7}-10^{-5} \mathrm{~S} \mathrm{~cm}^{-1}\right.$ at $\left.120^{\circ} \mathrm{C}\right)$ [44], and they are better considered as anode materials [11, 45]. Another interesting class reported is the rare earth and chloride-containing materials from the $\operatorname{LiRE}\left(\mathrm{BH}_{4}\right)_{3} \mathrm{Cl}$ family (with $\mathrm{RE}=\mathrm{Ce}, \mathrm{La}, \mathrm{Gd}$ ), for which conductivities of up to $2 \times 10^{-4} \mathrm{~S} \mathrm{~cm}^{-1}$ are reported at room temperature [46]. These examples highlight that the high ionic conductivities found in $\mathrm{LiBH}_{4}$-based materials are by no means an exception, but in fact that high ionic conductivities are quite common in complex metal hydrides compounds, and hence, it is likely that many more potentially interesting materials will be synthesised and reported in the coming years. Having said that, existing literature also makes clear that moving towards increasingly complex materials, and increasing the number of elements and hence possible phases in the systems, makes it more and more a challenge to obtain phase-pure compounds, and is often not accompanied by a high stability upon cycling or temperature treatment.

\section{$6 \mathrm{Na}^{+}$superionic conductors}

Due to fear of future lithium scarcity and hence high costs, also batteries based on other metals, such as $\mathrm{Na}^{+}, \mathrm{Mg}^{2+}$, and $\mathrm{Al}^{3+}$, are being intensively investigated as lower-cost alternatives, with especially $\mathrm{Na}^{+}$-based batteries attracting much attention [47]. As there are many similarities and trends across the family of complex metal hydride materials, a logical next step is to explore also compounds based on other alkali or alkaline earth cations. Orimo and co-workers found that $\mathrm{Na}_{2}\left(\mathrm{BH}_{4}\right)\left(\mathrm{NH}_{2}\right)$ obtained in the system $\mathrm{NaBH}_{4}-\mathrm{NaNH}_{2}$ shows a conductivity of $2 \times 10^{-6} \mathrm{~S} \mathrm{~cm}^{-1}$ at $300 \mathrm{~K}$ [48]. Udovic and others reported in 2014 for the first time on the high ionic mobilities and conductivities for sodium borohydrides (Fig. 4). Interesting candidates are $\mathrm{Na}_{2} \mathrm{~B}_{12} \mathrm{H}_{12}$ (which exhibits a transition to high ionic conductivity at $205^{\circ} \mathrm{C}$ ) and $\mathrm{Na}_{2} \mathrm{~B}_{10} \mathrm{H}_{10}$ (which in pure form becomes conducting above $\left.\sim 100{ }^{\circ} \mathrm{C}\right)[49,50]$.

\section{Integration of these solid electrolytes into a battery}

Optimising one component is not yielding a commercially viable battery, as compatibility with the other components in the system is crucial for real

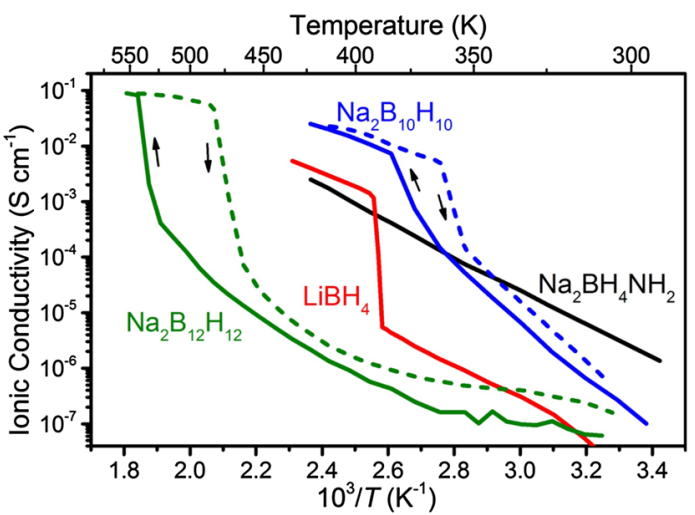

Fig. 4 Overview of some recently reported sodium boron hydrides showing interestingly high ionic conductivities [49, 50]. The conductivity of $\mathrm{LiBH}_{4}$ is shown for comparison

application. Most efforts for the construction of allsolid-state batteries based on complex metal hydride electrolytes have been focussed on $\mathrm{LiBH}_{4}$ [51-54]. $\mathrm{LiBH}_{4}$ is stable in contact with metallic lithium, but its stability at the interface with the positive electrode, while facilitating fast and totally reversible exchange of $\mathrm{Li}^{+}$ions with the electrode, is a challenge. First attempts were made with a $\mathrm{LiCoO}_{2}$ electrode, intrinsically unstable in contact with $\mathrm{LiBH}_{4}$ operated in the high-temperature phase (at $120^{\circ} \mathrm{C}$ ), but the stability and reversibility were much improved by applying a $\mathrm{Li}_{3} \mathrm{PO}_{4}$ coating between the $\mathrm{LiCoO}_{2}$ and $\mathrm{LiBH}_{4}$ [50]. Also $\mathrm{TiS}_{2}$ was tested as a positive electrode [53], and the solid electrolyte was even combined with a metal hydride negative electrode [54]. More details on complex metal hydrides for bulk-type all-solid-batteries can be found in [28].

\section{Conclusions and outlook}

It is clear that for future-generation, higher-capacity, lithium-ion batteries, solid-state electrolytes are a crucial component. Complex metal hydrides, and specifically $\mathrm{LiBH}_{4}$-based compounds, have recently been shown to be a promising class of fast-ionic conductors. Although intrinsically macrocrystalline $\mathrm{LiBH}_{4}$ displays high conductivities only at temperatures above $110{ }^{\circ} \mathrm{C}$, more recent strategies such as partial anion substitution and nanoconfinement have been developed that lead also to high conductivities at room temperature. Yet, $\mathrm{LiBH}_{4}$ is not unique, and many other complex metal hydrides containing $\mathrm{Li}^{+}$as well as $\mathrm{Na}^{+}$and probably other cations also exhibit high ionic conductivities. It is evident that we still need a more fundamental understanding of the ionic mobilities in these compounds, and how they can be influenced by such 
strategies as anion replacement and nanoconfinement. Also crucial is a better understanding of their chemical and electrochemical stabilities, most notably pertaining to their interface interactions with the positive electrode. Nevertheless, it is clear that this rapidly expanding family of complex metal hydrides with high room-temperature conductivities provides for a rather intriguing area of fundamental scientific research that can ultimately lead to exciting practical applications for these materials in nextgeneration, all-solid-state, lithium-ion, and other rechargeable batteries.

Acknowledgments The IEA HIA Task 32-Hydrogen-Based Energy Storage is acknowledged for providing the opportunities for collaboration and fruitful discussions.

Open Access This article is distributed under the terms of the Creative Commons Attribution 4.0 International License (http://crea tivecommons.org/licenses/by/4.0/), which permits unrestricted use, distribution, and reproduction in any medium, provided you give appropriate credit to the original author(s) and the source, provide a link to the Creative Commons license, and indicate if changes were made.

\section{References}

1. J.B. Goodenough, K.S. Park, J. Am. Chem. Soc. 135, 1167 (2013)

2. P.G. Bruce, S.A. Freunberger, L.J. Hardwick, J.M. Tarascon, Nat. Mater. 11, 19 (2012)

3. H.G. Jung, J. Hassoun, J.B. Park, Y.K. Sun, B. Scrosati, Nat. Chem. 4, 579 (2012)

4. J.M. Tarascon, Philos. Trans. R. Soc. Math. Phys. Eng. Sci. 368, 3227 (2010)

5. Y. Kato, K. Kawamoto, R. Kanno, M. Hirayama, Electrochemistry 80, 749 (2012)

6. S.S. Zhang, J. Power Sources 231, 153 (2013)

7. A.C. Luntz, B.D. McCloskey, Chem. Rev. 114, 11721 (2014)

8. Y. Oumellal, A. Rougier, G.A. Nazri, J.-M. Tarascon, L. Aymard, Nat. Mater. 7, 916 (2008)

9. Y. Oumellal, C. Zlotea, S. Bastide, C. Cachet-Vivier, E. Leonel, S. Sengmany, E. Leroy, L. Aymard, J.-P. Bonnet, M. Latroche, Nanoscale 6, 14459 (2014)

10. J. Zhang, W. Zaïdi, V. Paul-Boncour, K. Provost, A. Michalowicz, F. Cuevas, M. Latroche, S. Belin, J.-P. Bonnet, L. Aymard, J. Mater. Chem. A 1, 4706 (2013)

11. K. Provost, J. Zhang, W. Zaidi, V. Paul-Boncour, J.-P. Bonnet, F. Cuevas, S. Belin, L. Aymard, M. Latroche, J. Phys. Chem. C 118, 29554 (2014)

12. J.A. Teprovich, J. Zhang, H. Colón-Mercado, F. Cuevas, B. Peters, S. Greenway, R. Zidan, M. Latroche, J. Phys. Chem. C 119, 4666 (2015)

13. W. Zaïdi, J.-P. Bonnet, J. Zhang, F. Cuevas, M. Latroche, S. Couillaud, J.-L. Bobet, M.T. Sougrati, J.C. Jumas, L. Aymard, Int. J. Hydrog. Energy 38, 4798 (2013)

14. Y. Oumellal, W. Zaïdi, J.-P. Bonnet, F. Cuevas, M. Latroche, J. Zhang, J.-L. Bobet, A. Rougier, L. Aymard, Int. J. Hydrog. Energy 37, 7831 (2012)

15. L. Grande, E. Paillard, J. Hassoun, J.B. Park, Y.J. Lee, Y.K. Sun, S. Passerini, B. Scrosati, Adv. Mater. 27, 784-800 (2015)

16. J.M. Tarascon, M. Armand, Nature 414, 359 (2001)
17. N. Kamaya, K. Homma, Y. Yamakawa, M. Hirayama, R. Kanno, M. Yonemura, T. Kamiyama, Y. Kato, S. Hama, K. Kawamoto, A. Mitsui, Nat. Mater. 10, 682 (2011)

18. D.S. Stasinevitch, G.A. Egorenko, Russ. J. Inorg. Chem. 13, 341 (1968)

19. B. Bogdanovic, M. Schwickardi, J. Alloys Compd. 253-254, 1 (1997)

20. A. Züttel, S. Rentsch, P. Fischer, P. Wenger, P. Sudan, P. Mauron, C. Emmenegger, J. Alloys Compd. 356-357, 515 (2003)

21. B.A. Boukamp, R.A. Huggins, Phys. Lett. A 72, 464 (1979)

22. M. Matsuo, S. Orimo, Adv. Energy Mater. 1, 161 (2011)

23. M. Matsuo, Y. Nakamori, S. Orimo, H. Maekawa, H. Takamura, Appl. Phys. Lett. 91, 4103 (2007)

24. T. Ikeshoji, E. Tsuchida, T. Morishita, K. Ikeda, M. Matsuo, Y. Kawazoe, S. Orimo, Phys. Rev. B 83, 144301 (2011)

25. J.P. Soulié, G. Renaudin, R. Erný, K. Yvon, J. Alloys Compd. 346, 200 (2002)

26. P.C. Aeberhard, K. Refson, W.I.F. David, Phys. Chem. Chem. Phys. 15, 8081 (2013)

27. Y. Filinchuk, D. Chernyshov, R. Cerny, J. Phys. Chem. C 112, 10579 (2008)

28. A. Unemoto, M. Matsuo, S. Orimo, Adv. Funct. Mater. 24, 2267 (2014)

29. J.S.G. Myrdal, D. Blanchard, D. Sveinbjörnsson, T. Vegge, J. Phys. Chem. C 117, 9084 (2013)

30. V. Epp, M. Wilkening, Phys. Rev. B 82, 020301 (2010)

31. A.V. Skripov, A.V. Soloninin, L.H. Rude, T.R. Jensen, Y. Filinchuk, J. Phys. Chem. C 116, 26177 (2012)

32. D. Sveinbjörnsson, J.S.G. Myrdal, D. Blanchard, J.J. Bentzen, T. Hirata, M.B. Mogensen, P. Norby, S. Orimo, T. Vegge, J. Phys. Chem. C 117, 3249 (2013)

33. L.M. Arnbjerg, D.B. Ravnsbæk, Y. Filinchuk, R.T. Vang, Y. Cerenius, F. Besenbacher, J.E. Jørgensen, H.J. Jakobsen, T.R. Jensen, Chem. Mater. 21, 5772 (2009)

34. A. Remhof, P. Mauron, A. Züttel, J.P. Embs, Z. Łodziana, A.J. Ramirez-Cuesta, P. Ngene, P. de Jongh, J. Phys. Chem. C 117, 3789 (2013)

35. D.T. Shane, R.L. Corey, C. McIntosh, L.H. Rayhel, R.C. Bowman, J.J. Vajo, A.F. Gross, M.S. Conradi, J. Phys. Chem. C 114, 4008 (2010)

36. X. Liu, E.H. Majzoub, V. Stavila, R.K. Bhakta, M.D. Allendorf, D.T. Shane, M.S. Conradi, N. Verdal, T.J. Udovic, S.-J. Hwang, J. Mater. Chem. A 1, 9935 (2013)

37. M.H.W. Verkuijlen, P. Ngene, D.W. de Kort, C. Barré, A. Nale, E.R.H. van Eck, P.J.M. van Bentum, P.E. de Jongh, A.P.M. Kentgens, J. Phys. Chem. C 116, 22169 (2012)

38. P. Ngene, P. Adelhelm, A.M. Beale, K.P. De Jong, P.E. De Jongh, J. Phys. Chem. C 114, 6163 (2010)

39. D. Blanchard, A. Nale, D. Sveinbjörnsson, T.M. Eggenhuisen, M.H.W. Verkuijlen, S. Suwarno, T. Vegge, A.P.M. Kentgens, P.E. de Jongh, Adv. Funct. Mater. 25, 184 (2015)

40. N. Verdal, T.J. Udovic, J.J. Rush, X. Liu, E.H. Majzoub, J.J. Vajo, A.F. Gross, J. Phys. Chem. C 117, 17983 (2013)

41. F.W. Poulsen, N.H. Andersen, B. Kindl, J. Schoonman, Solid State Ion. 9-10, 119 (1983)

42. V.G. Ponomareva, G.V. Lavrova, L.G. Simonova, Solid State Ion. 119, 295 (1999)

43. C.C. Liang, J. Electrochem. Soc. 120, 1289 (1973)

44. H. Oguchi, M. Matsuo, T. Sato, H. Takamura, H. Maekawa, H. Kuwano, S. Orimo, J. Appl. Phys. 107, 6104 (2010)

45. L. Silvestri, S. Forgia, L. Farina, D. Meggiolaro, S. Panero, A. La Barbera, S. Brutti, P. Reale, ChemElectroChem 2, 877 (2015)

46. M.B. Ley, S. Boulineau, R. Janot, Y. Filinchuk, T.R. Jensen, J. Phys. Chem. C 116, 21267 (2012)

47. P. Hartmann, C.L. Bender, M. Vračar, A.K. Dürr, A. Garsuch, J. Janek, P. Adelhelm, Nat. Mater. 12, 228 (2013) 
48. M. Matsuo, S. Kuromoto, T. Sato, H. Oguchi, H. Maekawa, H. Takamura, S. Orimo, Appl. Phys. Lett. 100, 203904 (2012)

49. T.J. Udovic, M. Matsuo, A. Unemoto, N. Verdal, V. Stavila, A.V. Skripov, J.J. Rush, H. Takamura, S. Orimo, Chem. Commun. 50, 3750 (2014)

50. T.J. Udovic, M. Matsuo, W.S. Tang, H. Wu, V. Stavila, A.V. Soloninin, R.V. Skoryunov, O.A. Babanova, A.V. Skripov, J.J. Rush, A. Unemoto, H. Takamura, S. Orimo, Adv. Mater. 26, 7622 (2014)
51. K. Takahashi, K. Hattori, T. Yamazaki, K. Takada, M. Matsuo, S. Orimo, H. Maekawa, H. Takamura, J. Power Sources 226, 61 (2013)

52. D. Sveinbjörnsson, A.S. Christiansen, R. Viskinde, P. Norby, T. Vegge, J. Electrochem. Soc. 161, A1432 (2014)

53. A. Unemoto, T. Ikeshoji, S. Yasaku, M. Matsuo, V. Stavila, T.J. Udvic, S. Orimo, Chem. Mater. 27, 5407 (2015)

54. L. Zeng, K. Kawahito, S. Ikeda, T. Ichikawa, H. Miyaoka, Y. Kojima, Chem. Commun. 51, 9773 (2015) 